\title{
Actinomyces species: A Danish Survey on Human Infections and Microbiological Characteristics
}

\author{
J.M. Hansen ${ }^{1,2, *}$, H. Fjeldsøe-Nielsen ${ }^{1,3}$, S. Sulim ${ }^{1,4}$, M. Kemp ${ }^{1}$ and J.J. Christensen ${ }^{1}$ \\ ${ }^{I}$ Department of Bacteriology, Mycology and Parasitology, Statens Serum Institute, Copenhagen, Departments of \\ Clinical Microbiology at ${ }^{2}$ Hvidovre Hospital, Hvidovre, ${ }^{3}$ Naestved Hospital, Naestved and ${ }^{4}$ Viborg Hospital, Viborg, \\ Denmark
}

\begin{abstract}
This study compared phenotypic and genotypic identification of Actinomyces strains, tested susceptibility to antibiotics and evaluated their clinical importance. Thirty-four Actinomyces strains were examined; sixteen type strains, and 18 clinical strains from different hospitals in Denmark from the period 2003-2005. Partial 16S rDNA sequencing using a stretch of 526 bases was used for genotypic identification. Susceptibility testing was done by E-test. The antibiotics examined were: benzylpenicillin, piperacillin with tazobactam, ceftriaxone, meropenem, erythromycin, clindamycin, linezolid, moxifloxacin, tetracycline and tigecycline. Clinical parameters were obtained by reviewing patient records. There was poor agreement between the phenotypic and genotypic identification. Phenotypic tests were helpful in identifying strains closely related by DNA sequences. The strains were sensitive to the examined antibiotics except for moxifloxacin to which most strains were resistant, and a few strains were resistant to meropenem and tetracycline. The clinical strains were from many different types of infections and locations. None of the patients was described as having typical actinomycetic lesions, and an apparently good outcome was obtained with different treatment regimens.
\end{abstract}

Keywords: Actinomyces species, Bacterial identification, phenotypic characterization, partial 16S rDNA sequencing.

\section{INTRODUCTION}

The genus Actinomyces consists of a heterogeneous group of anaerobic and facultative anaerobic, asporogenous, Gram-positive, non-acid-fast, rod-shaped organisms [1], many of which occur as inhabitants of mucosal surfaces, particularly the oral cavity, of humans and animals. Actinomyces species can cause actinomycosis, a chronic granulomatous lesion, forming suppurative abscesses and draining sinuses. Localization is most often cervicofacial (60\%), thoracic $(15 \%)$ or abdominal $(20 \%)$ [1]. Both laboratory identification and clinical diagnosis is often troublesome. Coryneform bacteria are difficult to classify at the species or even at the genus level [2] and poses major problems for clinical microbiology laboratories in terms of labour, time, and cost, when conventional methods are used. Panels of phenotypic characteristics useful in identifying species have been described by Funke et al. [2] and Sarkonen et al. [3].

An increased recognition of the importance of coryneform bacteria as opportunistic human pathogens within the last decade [4], has occurred in a period where new diagnostic tools for identification of bacteria progressively have been introduced. These techniques, especially sequencing of genes coding for rRNA have revolutionized the insight into phylogeny and taxonomy of bacteria.

We therefore found it relevant to characterize 34 strains of Actinomyces species from humans, 18 recent Danish

*Address correspondence to this author at the Department of Clinical Microbiology, Hvidovre Hospital, Kettegaard Allé 30, 2650 Hvidovre, Denmark; E-mail: jmh07@dadlnet.dk clinical strains and 16 type strains of different species, using a recent phenotypical identification scheme, and compare the results to genotypic identification using partial $16 \mathrm{~S}$ rDNA sequencing. In addition, susceptibility to antibiotics was determined and data on clinical manifestations of the respective patients was obtained.

\section{MATERIALS AND METHODS}

\section{Bacterial Strains}

We examined 34 Actinomyces strains. Sixteen type strains, received from CCUG (Culture Collection, University of Göteborg, Göteborg, Sweden), were included: $A$. europaeus CCUG $32789 \mathrm{~A}^{\mathrm{T}}$, A. funkei CCUG $42773^{\mathrm{T}}$, A. georgiae CCUG $32935^{\mathrm{T}}$, A. gerencseriae CCUG $32936^{\mathrm{T}}$, A. graevenitzii CCUG $27294^{\mathrm{T}}$, A. israelii CCUG $18307^{\mathrm{T}}$, A. meyeri CCUG $21024^{\mathrm{T}}$, A. naeslundii CCUG $18310^{\mathrm{T}}$, A. neuii subsp. neuii CCUG $32252^{\mathrm{T}}$, A. neuii subsp. anitratus CCUG $32253^{\mathrm{T}}$, A. odontolyticus CCUG $20536^{\mathrm{T}}$, A. radicidentis CCUG $36733^{\mathrm{T}}$, A. radingae CCUG $32394^{\mathrm{T}}$, A. turicensis CCUG $34269^{\mathrm{T}}$, A. urogenitalis CCUG $38702^{\mathrm{T}}$, A. viscosus CCUG $14476^{\mathrm{T}}$. Eighteen strains were clinical strains submitted from Danish Departments of Clinical Microbiology to the National Reference Laboratory for identification of bacteria, at Statens Serum Institut (SSI), in the period February 2003 - March 2005. All strains were kept as frozen $\left(-80^{\circ} \mathrm{C}\right)$ stocks.

\section{Phenotypic Identification}

The strains were subcultured on $10 \%$ horse blood agar (SSI Diagnostica, Hillerød, Denmark), and the agar plates 
were incubated for five days at $35{ }^{\circ} \mathrm{C}$ in ambient air, a $\mathrm{CO}_{2}$ enriched (5\%) and an anaerobic atmosphere, respectively. Colonial morphology and microscopic appearance in Gramstained preparations were noted. CAMP reaction was examined on CAMP agar (SSI Diagnostica) with a betahemolysin-producing strain of Staphylococcus aureus. CAMP-plates were incubated at $35{ }^{\circ} \mathrm{C}$ in a $\mathrm{CO}_{2}$-enriched $(5$ $\%$ ) and an anaerobic atmosphere, respectively, and were read after 24-h and 48-h incubation. Testing for nitrate reduction was performed using a nitrate broth culture (semi-solid agar) incubated at $35{ }^{\circ} \mathrm{C}$ in an anaerobic atmosphere for a minimum of five days, prior to addition of sulfanilic acid, Cleves acid, and if necessary zinc powder [5, 6]. Rosco diagnostic tablets (Rosco A/S, Taastrup, Denmark) were used for testing hydrolysis of urea and esculin, production of $\alpha$-fucosidase, $\alpha$-glucosidase, $\quad \beta$ - $\mathrm{N}$-acetylglucosaminidase $(\beta-\mathrm{NAG})$ and $\beta$-galactosidase (ONPG), and acid production from L-arabinose, following the instructions of the manufacturer. A. israelii and A. gerencseriae were differentiated from each other by the presence of $\alpha$-mannosidase and arginine dihydrolase (ADH). Acid production from Larabinose, maltose, mannitol, raffinose, rhamnose, sucrose, xylose and trehalose was tested in tubes with extractbouillon and the carbohydrate (SSI Diagnostica) [6], incubated at $35{ }^{\circ} \mathrm{C}$ in an anaerobic atmosphere for a minimum of five days. Horse citrate plasma was added to promote growth. All tests, except testing for the presence of $\alpha$ mannosidase, were performed by more than one method, as the strains were also tested with the API ${ }^{\circledR}$ strips, Rapid ID $32 \mathrm{~A}$ and API 20 A® (bioMérieux ${ }^{\circledR}$ as, Marcy l'Etoile, France) following the instructions of the manufacturer. Rapid ID 32 A tested: ability to reduce nitrate, the presence of urease, $\alpha$-fucosidase, $\alpha$-glucosidase, $\beta$-NAG, ONPG and $\mathrm{ADH}$, and acid production from raffinose. API $20 \mathrm{~A}{ }^{\circledR}$ tested: presence of urease, hydrolysis of esculin, acid production from arabinose, maltose, mannitol, raffinose, rhamnose, sucrose, xylose and trehalose. Catalase was detected with $10 \% \mathrm{H}_{2} \mathrm{O}_{2}$ in a well in the API $20 \mathrm{~A}{ }^{\circledR}$ strip with a positive reaction.

\section{Ribosomal DNA Sequencing}

For molecular biological study DNA was released by heating isolated bacteria at $95^{\circ} \mathrm{C}$ for $5 \mathrm{~min}$. PCR amplification of part of the $16 \mathrm{~S}$ rRNA gene was performed using the primers BSF-8 and BSR-534 as previously described [7]. DNA sequences were aligned and edited at http://bioinfo. genotoul.fr/multalin/multalin.html resulting in comparable sequences ranging from 324 to 351 basepairs. Furthermore, all edited sequences were compared to deposited sequences in the Bio Informatic Bacteria Identification database. Sequences obtained for clinical strains were compared to original CCUG sequences of collection strains. Results were illustrated in a phylogentic tree using CLC workbench 4.5 software.

\section{Susceptibility Testing}

The MICs of all the strains were determined using E-test (AB Biodisk, Solna, Sweden) for the following antibiotics: benzylpenicillin, piperacillin with tazobactam, ceftriaxone, meropenem, erythromycin, clindamycin, linezolid, moxifloxacin, tetracycline, and tigecycline. All tests were per- formed on anaerobic plates (SSI Diagnostica). Plates were inoculated with the bacterial isolates in API suspension medium (demineralised water) (bioMérieux ${ }^{\circledR}$ as, Marcy l'Etoile, France) with a turbidity equivalent of McFarland standard 4,0 [8] and incubated anaerobically at $35^{\circ} \mathrm{C}$ for 48 72 hours. Results were read according to the manufacturer's guidelines. Quality controls were performed using Bacteroides fragilis (ATCC 25285). MIC measurements (at least triplicate) for the control strain were as follows: Penicillin: $>32 \mu \mathrm{g} / \mathrm{ml}$, piperacillin/tazobactam: $0.25-0.5 \mu \mathrm{g} / \mathrm{ml}$, ceftriaxone: $32 \mu \mathrm{g} / \mathrm{ml}$, meropenem: $0.064 \mu \mathrm{g} / \mathrm{ml}$, erythromycin: $1.5 \mu \mathrm{g} / \mathrm{ml}$, clindamycin: $0.75-2.0 \mu \mathrm{g} / \mathrm{ml}$, linezolid: $1.5 \mu \mathrm{g} / \mathrm{ml}$.

\section{Clinical Data}

Information on predisposing factors, actual diagnosis and antibiotic treatment was recorded from patient files.

\section{RESULTS}

\section{Phenotypic Identification}

The appearance of the strains varied both in the Gramstained preparations and with growth on agar. Microscopically many strains were without visible branching, many were small rods with an appearance similar to the coryneforms, other were coccoid or long and curved rods. On agar most strains were grey or white, colony-sizes ranged from pinpoint to three $\mathrm{mm}$ in diameter, and some had $\alpha$ haemolysis. Colonies could be rough or smooth, elevated or flat, and some adhered to agar. The incubation atmosphere influenced appearance and growth; some strains did not grow in ambient air.

Table 1 shows results of phenotypic identification of Actinomyces strains following the recommendations of Sarkonen et al. [3]. All type strains were correctly identified. We used the same type strains as Sarkonen et al. except for the type strain of $A$. israelii. The clinical strains were grouped from the phenotypic identification; one strain could not be designated to a species by the performed phenotypic characterization.

Results of individual biochemical reactions sometimes differed when tested with different methods. This was for example seen when testing nitrate reduction, esculin hydrolysis and acid production from carbohydrates.

\section{Genotypic Identification}

All type strains were correctly identified. For the 16 type strains best taxon match had scores from 642 to 672 bits and differences to next best taxon matches between 22 and 260 bits. Some species were more closely related than others; A. meyerii and A. odontolyticus were most closely related, followed by $A$. viscosus and A. naeslundii. A. radingae was least connected to the other species. For 18 clinical strains scores of 480 to 670 bits were found with differences to next best taxon matches between 2 and 245 bits.

One of the clinical strains could not be allocated to a species on phenotypic characteristics, wherefore 17 clinical strains could be compared (Fig. 1). 
Table 1. Results from Phenotypic Identification of Strains of Actinomyces ${ }^{\mathrm{a}}$

\begin{tabular}{|c|c|c|c|c|c|c|c|c|c|c|c|c|c|c|c|c|c|c|}
\hline \multirow[b]{2}{*}{$\begin{array}{l}\text { Species and } \\
\text { Strain(s) }\end{array}$} & \multirow[b]{2}{*}{ Pigment } & \multirow[b]{2}{*}{ Catalase } & \multirow[b]{2}{*}{$\begin{array}{c}\text { Nitrate } \\
\text { Reduction }\end{array}$} & \multirow[b]{2}{*}{$\begin{array}{c}\text { CAMP } \\
\text { Test }\end{array}$} & \multicolumn{2}{|c|}{ Hydrolysis of: } & \multicolumn{4}{|c|}{ Production of: } & \multicolumn{8}{|c|}{ Fermentation of: } \\
\hline & & & & & Urea & Esculin & $\begin{array}{c}\alpha \text {-Fuco- } \\
\text { sidase }\end{array}$ & $\begin{array}{c}\alpha \text {-Gluco- } \\
\text { sidase }\end{array}$ & $\begin{array}{c}\beta- \\
\text { NAG }\end{array}$ & $\left|\begin{array}{c}\beta \text {-Galac- } \\
\text { tosidase }\end{array}\right|$ & $\begin{array}{c}\text { Arab- } \\
\text { inose }\end{array}$ & $\begin{array}{l}\text { Mal- } \\
\text { tose }\end{array}$ & $\begin{array}{l}\text { Man- } \\
\text { nitol }\end{array}$ & $\begin{array}{c}\text { Raffi- } \\
\text { nose }\end{array}$ & $\begin{array}{c}\text { Rham- } \\
\text { nose }\end{array}$ & $\begin{array}{l}\text { Suc- } \\
\text { rose }\end{array}$ & $\begin{array}{l}\mathrm{Xy}- \\
\text { lose }\end{array}$ & $\begin{array}{c}\text { Tre- } \\
\text { halose }\end{array}$ \\
\hline $\begin{array}{c}\text { A. europaeus } \\
\text { CCUG } 32789 \mathrm{~A}^{\mathrm{T}}\end{array}$ & - & - & + & - & - & + & - & + & - & + & - & + & - & - & - & $\mathrm{v}$ & - & - \\
\hline $\begin{array}{c}\text { A. funkei } \\
\text { CCUG } 42773^{\mathrm{T}}\end{array}$ & - & - & + & - & - & - & + & + & - & $\mathrm{v}$ & $\mathrm{v}$ & $\mathrm{v}$ & - & - & + & + & + & - \\
\hline $\begin{array}{c}\text { A. georgiae } \\
\text { CCUG } 32935^{\mathrm{T}}\end{array}$ & - & - & $\mathrm{v}$ & - & - & $\mathrm{v}$ & - & + & - & + & - & + & - & $\mathrm{v}$ & + & + & + & + \\
\hline $\begin{array}{c}\text { A. gerencseriae } \\
\text { CCUG } 32936^{\mathrm{T}}, 1 \\
\text { clinical strain }\end{array}$ & - & - & $\mathrm{v},-$ & - & - & + &,-+ & + & - & + &,$- \mathrm{v}$ & + & $\mathrm{v},+$ &,-+ & - & + & + & + \\
\hline $\begin{array}{l}\text { A. graevenitzii } \\
\text { CCUG } 27294^{\mathrm{T}}\end{array}$ & - & - & - & - & - & - & - & + & + & + & - & + & - & $\mathrm{v}$ & - & + & - & - \\
\hline $\begin{array}{c}\text { A. } \text { israelii } \\
\text { CCUG } 18307^{\mathrm{T}}, 2 \\
\text { clinical strains }\end{array}$ & - & - &,$+ \mathrm{v}$ & - & - & + & - & + & - & + & $\mathrm{v}$ & + & $\mathrm{v}$ & + & $\mathrm{v},-$ & + & + & + \\
\hline $\begin{array}{c}\text { A. meyeri CCUG } \\
21024^{\mathrm{T}}\end{array}$ & - & - & - & - & - & - & - & + & - & + & - & + & - & $\mathrm{v}$ & - & + & + & $\mathrm{v}$ \\
\hline $\begin{array}{l}\text { A. naeslundii } \\
\text { CCUG } 18310^{\mathrm{T}}\end{array}$ & - & - & + & - & - & + & - & + & - & + & - & + & - & + & - & + & - & + \\
\hline $\begin{array}{l}\text { A. neuii subsp. } \\
\text { Neuii } \\
\text { CCUG } 32252^{\mathrm{T}}, 2 \\
\text { clinical strains }\end{array}$ & - & + &,$+ \mathrm{v}$ & + & - & - & - & + & - & + & - & + & + & $\mathrm{v}$ & - & + & + &,$+ \mathrm{v}$ \\
\hline $\begin{array}{l}\text { A. neuii subsp. } \\
\text { anitratus } \\
\text { CCUG } 32253^{\mathrm{T}}\end{array}$ & - & + & - & + & - & + & - & + & - & + & - & + & + & + & - & + & + & + \\
\hline $\begin{array}{c}\text { A. odontolyticus } \\
\text { CCUG } 20536^{\mathrm{T}}, 2 \\
\text { clinical strains }\end{array}$ &,-+ & - & + & - & - &,$- \mathrm{v}$ &,$+ \mathrm{v}$ & + & - & + & - & + & - & $\mathrm{v}$ &,$+ \mathrm{v}$ & + & + & - \\
\hline $\begin{array}{l}\text { A. radicidentis } \\
{\text { CCUG } 36733^{\mathrm{T}}}^{\text {C. }}\end{array}$ & - & + & $\mathrm{v}$ & - & - & $\mathrm{v}$ & - & + & - & + & - & + & + & + & - & + & - & + \\
\hline $\begin{array}{c}\text { A. radingae } \\
{\text { CCUG } 32394^{\mathrm{T}}, 2} \text { clinical strains }\end{array}$ & - & - &,$- \mathrm{v}$ & - & - & $\mathrm{v},+$ & + & + & $\mathrm{v},-$ & + &,$+ \mathrm{v}$ & + & $\mathrm{v}$ &,$+ \mathrm{v}$ & - & + &,$+ \mathrm{v}$ &,$+ \mathrm{v}$ \\
\hline 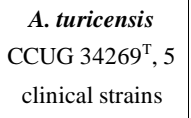 & - & - & - & - & - & - &,$+ \mathrm{v}$ & + & - &,$- \mathrm{v}$ &,$- \mathrm{v}$ & $\mathrm{v},+$ & - & - & - & + & + & - \\
\hline $\begin{array}{l}\text { A. urogenitalis } \\
\text { CCUG } 38702^{\mathrm{T}}\end{array}$ & - & - & + & - & - & + & - & + & + & + & $\mathrm{v}$ & + & - & + & + & + & + & + \\
\hline $\begin{array}{c}\text { A. viscosus } \\
\text { CCUG } 14476^{\mathrm{T}}, 3 \\
\text { clinical strains }\end{array}$ & - & + &,$- \mathrm{v}$ & - & - & $\mathrm{v}$ & - & + & - & + &,$- \mathrm{v}$ & + & - & + & - & + &,$- \mathrm{v}$ & $\mathrm{v}$ \\
\hline A. species & - & - & + & - & - & - & - & + & - & + & $\mathrm{v}$ & + & - & $\mathrm{v}$ & - & + & + & - \\
\hline
\end{tabular}

a -, negative result; +, positive result; $\mathrm{v}$, variable reaction (by different methods or among strains). Results for type strains are given first if different from the results obtained on clinical strains. 




Fig. (1). Phylogenetic tree illustrating the relationship between the 16 type strains and the 18 clinical strains. Six clinical strains did not reach concordance between genotypic / phenotypic* identification (five with different species names and one with no species identification). The remaining 12 strains were allocated to the same species when comparing the two methods of identification.

\section{Genotypic/Phenotypic Identification}

Ten of the 17 clinical strains showed methodological agreement at the species level. Two additional strains showed concordance as BLAST examinations could not separate (bits score difference $<30$ ) between A. viscosus and A. naeslundii; the latter was proposed from phenotypic characterization (and second BLAST choice) and the former from first BLAST choice. Thus, for 12 of 17 strains results from phenotypic and molecular examinations were in agreement. BLAST examinations for all strains seemed very convincing when taking all parameters into consideration (Fig. 1). Thus, for five of 17 clinical strains identifications by genotypic/phenotypic methods were in disagreement as indicated in Fig. (1) with an *. One isolate could not be designated to a species based on phenotypic characterization, which by genotypic identification belonged to the species $A$. meyerii. The isolates with disagreeing identifications were (genotypic/phenotypic identification): 1) A. odontolyticus/A. radingae $(\mathrm{n}=1), 2)$ A. radingae/A. gerencseriae $(\mathrm{n}=1), 3) A$. gerencseriae/A. israelii $(\mathrm{n}=1), 4)$ A. israelii/A. viscosus and 5) A. meyerii/A. turicensis.

\section{Susceptibility Testing}

The MICs for the 34 strains are shown in Table 2. All strains were sensitive to benzylpenicillin, piperacillin/ tazobactam, ceftriaxone, meropenem, erythromycin, clindamycin, linezolid, tetracycline and tigecycline, except for meropenem and tetracycline where one strain for each antibiotic had MIC values above the upper limits for sensitivity. Notably for moxifloxacin, 21 strains had MIC`s above the upper limit for being sensitive though most strains $(n=16)$ were close to the breaking point. We experienced difficulties reading zone diameters due to hazy zone edges, which explains why it was not possible to define an MIC value for 1-5 strains for each antibiotic.

\section{Clinical Data}

Table $\mathbf{3}$ shows clinical and microbiological data on the 18 patients from whom Actinomyces species were isolated. The patients have been divided into groups based on species designations from the genotypic identification. The clinical strains were chosen at random during the period February 2003 - March 2005. The median age was 54 years, 10 were men and 8 women.

The strains were from soft tissue infections (5 strains), blood (4), intraabdominal abscesses (3), periodontal infections (2), and one strain each from pus from bladder, empyema of the pleural space, spinal fluid and a swab from cornea. 
Table 2. Minimal Inhibitory Concentrations of 10 Antimicrobial Agents Against Actinomyces species. (n=34), Including Type Strains of 16 Different Species

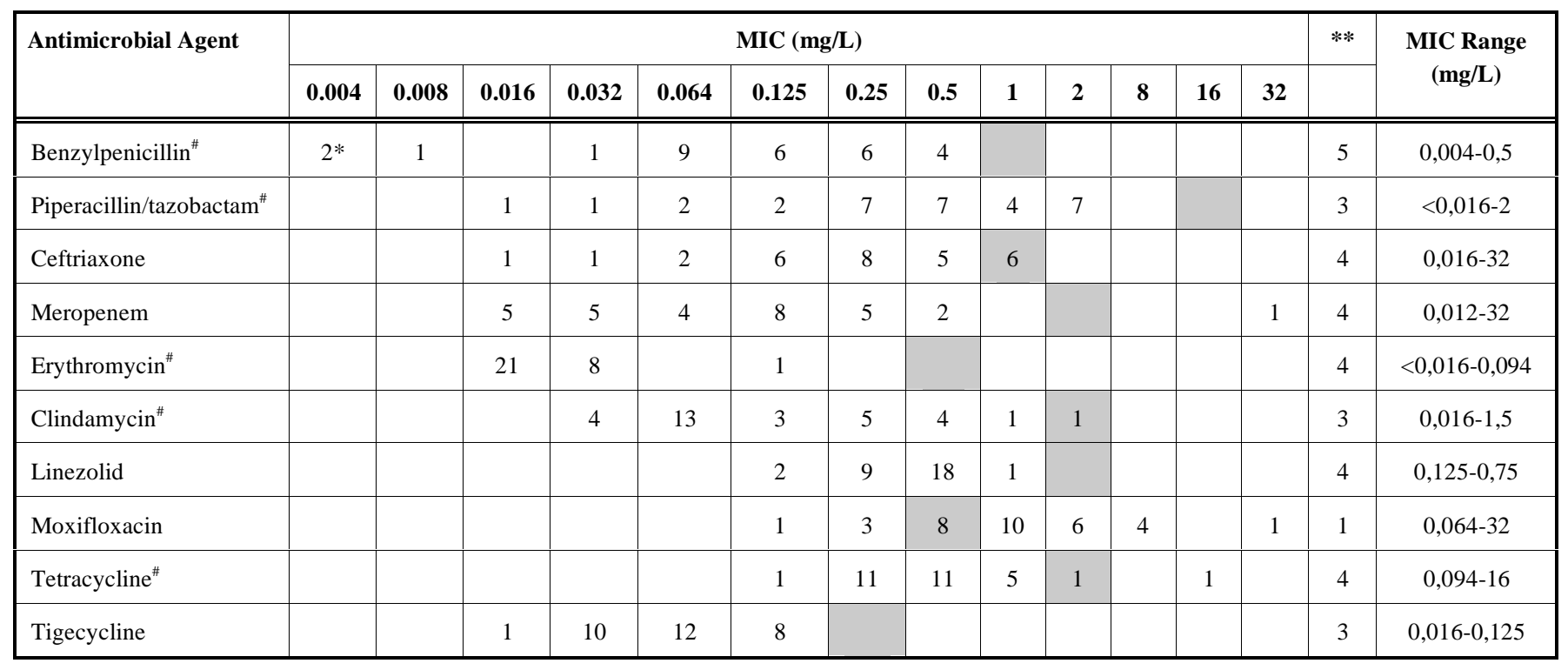

1)* Number of strains with adequate growth for reading MIC

2)** Number of strains with undefined MIC due to poor growth.

3) Grey shadings mark the upper limit for sensitivity according to international guidelines. Values above indicates resistance. (Pharmacological breakpoints 2007 from SRGA are used for antibiotics marked ${ }^{\#}$. Pk/pd breakpoints from EUCAST are used for the other antibiotics).

Nine patients received both surgical intervention and antibiotic treatment and, respectively, 5 and 4 patients received either antibiotic treatment or surgical intervention. When antibiotics were given, the $\operatorname{drug}(\mathrm{s})$ and duration varied, but always included $\beta$-lactam antibiotics. The following $\beta$-lactam antibiotics were used: penicillin, ampicillin, dicloxacillin, mecillinam, cefuroxime, ceftriaxone and meropenem. In some cases ciprofloxacin, gentamicin and metronidazole were added. The patient with keratitis was treated with topical agents containing chloramphenicol, tetracycline, polymyxin and gentamicin. All patients recovered, except one who died from other causes. Two patients had sequelae; one each with neurologic sequelae following meningitis and reduced vision following keratitis.

\section{DISCUSSION}

When describing the species A. europaeus in 1997 [2], Funke et al. used 15 phenotypic characteristics to differentiate the species from other human-derived, aerobically growing Actinomyces and Arcanobacterium species. In the scheme by Sarkonen et al. [3] using 18 characteristics, which also is used in this study, the same characteristics were used except that pyrazinamidase production and acid production from glucose plus glycogen was not tested for. However, additionally the scheme by Sarkonen et al. [3] takes into consideration pigmentation, production of $\alpha$-fucosidase and acid production from arabinose, raffinose, rhamnose and trehalose. The number of Actinomyces species has increased since these schemes were made. Often new species have been created from subgroups of existing species, complicating the destinction between species based on phenotypic characteristics as inclusion of new tests have been needed for differentiation between species [1]. The fact that the same reaction done with different methods, as also seen in this study, may result in diverse results complicates phenotypic identification even more. Recently, former genospecies 1 and 2 of $A$. naeslundii have been validly published as A. oris sp. nov. and A. johnsonii sp. nov.; these new species cannot be readily differentiated using conventional phenotypic testing [9]. All these developments stresses the need for applicating molecular methods for identification of Actinomyces.

Actinomyces species has a varied appearance in the microscope. It may be the typical Gram-positive branching bacilli, which often present with a beaded appearance, but not seldom more coccoid or variable forms occurs. Likewise, the typical molar tooth appearance of $A$. israelii may be absent. The appearance may be similar to common relatively avirulent pathogens, which often may be present together with Actinomyces species. It is therefore likely that Actinomyces sometimes is overlooked in samples. Misidentifications or non-identifications are presumed to occur in the routine microbiology laboratory. 16S rRNA gene sequence analysis has shown to be a powerful test in confirming or identifying suspected or non-identified Actinomyces species.

Three of the examined strains had very low differences in scores between best and next best taxon matches. When examining phylogenetic trees based on a comparison of approximately 1,320 nucleotides, A. meyerii and A. odontolyticus, and $A$. viscosus and A. naeslundii, are closely related explaining the low bits-differences [2]. Results of phenotypic reaction may be helpful in species identification in such cases. All in all, 16S rDNA sequencing of a 526 basepair stretch gave a good separation into proposed species. 
Table 3. Clinical and Microbiological Data on 18 Patients from whom Actinomyces species were Isolated

\begin{tabular}{|c|c|c|c|c|c|c|c|}
\hline $\begin{array}{l}\text { Species/ no. of } \\
\text { Isolates }\end{array}$ & $\begin{array}{l}\text { Age } \\
\text { Land Sex }\end{array}$ & Isolated from & Underlying Illness & $\begin{array}{l}\text { Major Clinical } \\
\text { Manifestations }\end{array}$ & Coisolates & Treatment & Outcome \\
\hline A. odontolyticus/ 1 & $56 \mathrm{~F}$ & blood & cirrhosis & $\begin{array}{l}\text { bloody vomiting } \\
\text { and diarrhoea }\end{array}$ & $-{ }^{a}$ & antibiotics $(\mathrm{m}, \mathrm{mt})$ & $\begin{array}{l}\text { death from other } \\
\text { causes }\end{array}$ \\
\hline \multirow[t]{4}{*}{ A. turicensis/ 4} & $24 \mathrm{~F}$ & pus (nates) & $-{ }^{\mathrm{a}}$ & $\begin{array}{l}\text { soft tissue abscess } \\
\text { on nates }\end{array}$ & - & surgery & recovery \\
\hline & $56 \mathrm{M}$ & tissue (necrotic) & $\begin{array}{l}\text { extraction of } \\
\text { infected tooth }\end{array}$ & $\begin{array}{l}\text { fasciitis of face and } \\
\text { neck }\end{array}$ & $\begin{array}{l}\text { H. parainfluenzae, NHS, } \\
\text { CNS, Prevotella spp. }\end{array}$ & $\begin{array}{l}\text { surgery, } 17 \text { and } \\
\text { later } 15 \text { days of } \\
\text { antibiotics }(\mathrm{p} / \mathrm{cu}+\mathrm{mt}, \mathrm{d})\end{array}$ & recovery \\
\hline & $63 \mathrm{~F}$ & pus (bladder) & chronic dialysis & cystitis & B. fragilis, CNS & $\begin{array}{l}\text { rinsing of the bladder, } \\
25 \text { days of antibiotics } \\
(\mathrm{d}, \mathrm{ci}+\mathrm{mt})\end{array}$ & recovery \\
\hline & $46 \mathrm{~F}$ & pus (rectum) & - & rectum abscess & - & $\begin{array}{l}\text { drainage, } 6 \text { weeks of } \\
\text { antibiotics (p, g, mt, } \\
\text { followed by p alone) }\end{array}$ & recovery \\
\hline \multirow[t]{2}{*}{ A. neuii/ 2} & $91 \mathrm{M}$ & blood & $\begin{array}{l}\text { chronic } \\
\text { nephropathy }\end{array}$ & cystitis & - & $\begin{array}{l}9 \text { days of antibiotics } \\
(\mathrm{cu}, \mathrm{mc})\end{array}$ & recovery \\
\hline & $67 \mathrm{M}$ & blood & $\begin{array}{l}\text { surgery of } \\
\text { ureter-stenosis }\end{array}$ & perirenal abscess & CNS, coryneforms & $\begin{array}{l}\text { drainage, } \min .37 \text { days } \\
\text { of antibiotics } \\
(a, \text { followed by } p+c i)\end{array}$ & recovery \\
\hline \multirow[t]{4}{*}{ A. meyeri/ 4} & $34 \mathrm{M}$ & pus (cheek) & $\begin{array}{l}\text { extraction of } \\
\text { infected tooth }\end{array}$ & $\begin{array}{l}\text { soft tissue abscess } \\
\text { on cheek }\end{array}$ & - & $\begin{array}{l}\text { surgery and } \\
\text { antibiotics (d) }\end{array}$ & $\begin{array}{l}\text { *does not show for } \\
\text { check-up }\end{array}$ \\
\hline & $33 \mathrm{M}$ & root of a tooth & - & $\begin{array}{l}\text { periodontal } \\
\text { infection }\end{array}$ & throat-flora & $\begin{array}{l}\text { dental treatment and } \\
\text { antibiotics }(p)\end{array}$ & recovery \\
\hline & $36 \mathrm{M}$ & pus (pleura) & $\begin{array}{l}\text { cerebral palsy, } \\
\text { epilepsy }\end{array}$ & $\begin{array}{l}\text { empyema following } \\
\text { episode of } \\
\text { pneumonia }\end{array}$ & $\begin{array}{l}\text { microscopy also showed } \\
\text { Gram-pos. cocci in chains }\end{array}$ & $\begin{array}{l}\text { drainage, decorticatio, } \\
2-3 \text { weeks of antibiotics } \\
(\mathrm{cu}, \mathrm{mt})\end{array}$ & $\begin{array}{l}* \text { does not show for } \\
\text { check-up }\end{array}$ \\
\hline & $66 \mathrm{M}$ & pus (abdomen) & $\begin{array}{l}\text { long episode of } \\
\text { intermittent } \\
\text { diarrhoea }\end{array}$ & $\begin{array}{l}\text { periappendical } \\
\text { abscess }\end{array}$ & E. coli & drainage (twice) & recovery \\
\hline \multirow[t]{2}{*}{ A. israelii/ 2} & $38 \mathrm{M}$ & spinal fluid & alcoholism & meningitis & - & $\begin{array}{l}\text { antibiotics (initially high } \\
\text { doses of } p, a, c t)\end{array}$ & $\begin{array}{l}\text { neurologic } \\
\text { sequelae }\end{array}$ \\
\hline & $35 \mathrm{~F}$ & pus (abdomen) & - & $\begin{array}{l}\text { periappendical } \\
\text { abscess }\end{array}$ & - & $\begin{array}{l}\text { surgery, } 4 \text { days of } \\
\text { antibiotics (cu, mt) }\end{array}$ & recovery \\
\hline \multirow[t]{2}{*}{ A. radingae/ 2} & $52 \mathrm{M}$ & pus (scrotum) & - & $\begin{array}{l}\text { soft tissue abscess } \\
\text { of scrotum }\end{array}$ & $\begin{array}{l}\text { anaerobic Gram-pos. } \\
\text { cocci and Gram-neg. rods }\end{array}$ & $\begin{array}{l}\text { surgery, a prior to } \\
\text { hospitalization }\end{array}$ & recovery \\
\hline & $74 \mathrm{~F}$ & pus (back) & - & $\begin{array}{l}\text { soft tissue abscess } \\
\text { on the back }\end{array}$ & - & surgery & recovery \\
\hline A. viscosus/ 1 & $87 \mathrm{~F}$ & blood & COLD, Mb. cordis & source unknown & - & $\begin{array}{l}9 \text { days of antibiotics } \\
(\mathrm{cu}, \mathrm{p}, \mathrm{mc})\end{array}$ & recovery \\
\hline A. naeslundii/ 1 & $52 \mathrm{~F}$ & swab (cornea) & $\begin{array}{l}\text { treated thyroid } \\
\text { disease }\end{array}$ & $\begin{array}{l}\text { keratitis followed } \\
\text { injury of the cornea }\end{array}$ & $\begin{array}{l}\text { Lactobacillus sp. found } \\
\text { in other samples }\end{array}$ & topical antibiotics & reduced vision \\
\hline A. gerencseriae/ 1 & $66 \mathrm{M}$ & swab (oral cavity) & - & $\begin{array}{l}\text { periodontal } \\
\text { infection }\end{array}$ & - & $\begin{array}{l}\text { surgery, } 4 \text { weeks of } \\
\text { antibiotics (p) }\end{array}$ & recovery \\
\hline
\end{tabular}

$\mathrm{F}$, female, $\mathrm{M}$, male, ${ }^{\mathrm{a}}-$, none, ${ }^{*}$, assumed recovery

H., Hamophilus, B., Bacteroides, NHS, non-hemolytic streptococci, CNS, coagulase-negative staphylococci, pos., positive, neg., negative

a, ampicillin/amoxicillin, ci, ciprofloxacin, ct, ceftriaxone, cu, cefuroxime, d, dicloxacillin, g, gentamicin, m, meropenem, mc, mecillinam, mt, metronidazole, p, penicillin 
Sequence analysis is especially useful when a rapid identification is desired due to for example clinical circumstances. Thus, molecular bacterial identification is a powerful tool for national reference laboratories enhancing both the speed and validity of performed examinations. Using BLAST examinations may also be helpful in giving up to date taxonomic considerations.

In vitro antimicrobial susceptibility of Actinomyces species is quite predictable [10]. Strains are generally sensitive to $\beta$-lactams. However, some may exhibit higher MIC values as also shown by McNeil and Schaal. The medium we used for susceptibility testing contains L-cystein, which reduces the activity of $\beta$-lactam antibiotics [11]; therefore, underestimated susceptibility for these antimicrobial agents can be expected. Erythromycin was the most active antimicrobial agent in vitro, followed by tigecycline. Clindamycin, linezolid and tetracycline also showed good in-vitro activity with MICs within the therapeutic range for all strains, except one strain, that was resistant to tetracycline. It is important knowing that fluorquinolones generally have poor activity against Actinomyces species [10]. In agreement with this moxifloxacin for most strains in this study had MIC values above the upper limit for sensitivity. Susceptibility testing of Actinomyces species can be problematic; therefore, it would be relevant to elaborate standard guidelines for susceptibility testing procedure and to determine speciesspecific breakpoints.

In the article by Clarridge III and Zhang [12] a large number of clinical Actinomyces species were examined. Seventy-three strains were identified by genotypic identification. A. turicensis was the most frequently isolated species. With genotypic identification the most frequently identified species in our study were A. turicensis and A. meyeri. The normal niche of A. turicensis has been assessed [12] to be gastrointestinal, genital or skin in that area. Some strains were also isolated from abscesses of the face, neck, breast, chest and back. Our findings are in accordance with this, see Table 3. The normal niche of A. meyeri, A. israelii and A. odontolyticus was assessed to be oropharynx, and this is in accordance with three of our A. meyeri strains being from abscess of cheek, root of tooth and empyema of pleural space, respectively. Finally, A. radingae was associated with chronic soft tissue abscesses of the breast, chest and back, and the normal niche was assessed to be skin of the upper body. One of our two strains was from an abscess on the back.

Actinomyces is often difficult to diagnose and eradicate, needing surgery and a long course of antibiotics [13, 14]. Typical actinomycetic lesions contain between 1 and 10 bacterial species in addition to the pathogenic Actinomycetes [10]. We do not have information of typical actinomycotic lesions in our patients. Several of the patients did not receive antibiotics at all or only short courses of treatment with recovery. These cases were especially soft tissue infections, but also abscesses in the abdomen and positive blood cultures. Thus, it is important to be aware of that many infections involving Actinomyces species may not present as typical actinomycetic lesions. The great recovery rate may be associated to the wide range of antibiotic sensitivity (except quinolones) among Actinomyces species and that infections may have a milder/different course than the classic severe A. israelii infections and therefore not necessitating the very long periods of high doses of forenstance penicillin as otherwise recommended.

In conclusion, we find poor agreement between the phenotypic and genotypic identification of Actinomyces species. Phenotypic tests were helpful in identifying strains closely related by DNA sequences. The examined Actinomyces strains were in-vitro sensitive to many antibiotics including B-lactams, but not quinolones, and two strains were resistant to meropenem and tetracycline, respectively. Standard guidelines for susceptibility testing of Actinomyces are lacking. With a varied appearance, both microscopically and on agar, often looking like common relatively avirulent bacteria, Actinomyces may easily be overlooked in samples. Actinomyces can be present in infections without typical actinomycetic lesions, and some of these infections probably do not need the same aggressive and long treatment as actinomycosis.

\section{ACKNOWLEDGEMENT}

We thank the Departments of Clinical Microbiology in Denmark and the Hospital Departments where patients were admitted for their contributions and help in connection with this project. Many thanks to Annemarie Hesselbjerg, Sandra Isling and Rimtas Dargis for excellent technical support.

\section{CONFLICT OF INTEREST DECLARATION}

There are no relationships constituting dual or conflicting interests.

\section{REFERENCES}

[1] Könönen E, Wade W. Propionibacterium, Lactobacillus, Actinomyces, and Other Non-Spore-forming Anaerobic Gram-Positive Bacteria. In: Murray PR, Baron EJ, Jorgensen JH, Pfaller MA, Yolken RH, Eds. Manual of Clinical Microbiology, $9^{\text {th }}$ ed. Washington, DC: ASM Press 2007; pp. 872-888.

[2] Funke G, Alvarez N, Pascual C, et al. Actinomyces europaeus sp. nov., isolated from human clinical specimens. Int J Syst Bacteriol 1997; 47: 687-92.

[3] Sarkonen N, Könönen E, Summanen P, Könönen M, JousimiesSomer H. Phenotypic identification of Actinomyces and related species isolated from human sources. J Clin Microbiol 2001; 39: 3955-61.

[4] Tang YW, Von Graevenitz A, Waddington MG, et al. Identification of coryneform bacterial isolates by ribosomal DNA sequence analysis. J Clin Microbiol 2000; 38: 1676-8.

[5] Lautrop H, Høiby N, Bremmelgaard A, Korsager B, Eds. Bakteriologiske undersoegelsesmetoder. Danmark: FADL's Forlag 1979.

[6] Røder BL. Culture Media Manual (Substrathaandbogen), $1^{\text {st }}$ ed. Copenhagen: Statens Serum Institute 1993.

[7] Christensen JJ, Andresen K, Justensen T, Kemp M. Ribosomal DNA sequencing: experiences from use in the Danish National Reference Laboratory for Identification of Bacteria. APMIS 2005; 113: 621-8.

[8] Smith AJ, Hall V, Thakker B, Gemell CG. Antimicrobial susceptibility testing of Actinomyces species with 12 antimicrobial agents. J Antimicrob Chemother 2005; 56: 407-9.

[9] Henssge U, Do T, Radford DR, Gilbert SC, Clark D, Beighton D. Emended description of Actinomyces naeslundii and descriptions of Actinomyces oris sp. nov. and Actinomyces johnsonii sp. nov., 
previously identified as Actinomyces naeslundii genospecies 1, 2 and WVA 963. Int J Syst Evol Microbiol 2009, 59, 509-16.

[10] McNeil MM, Schaal KP. Actinomyces species (Actinomycoses). In: $\mathrm{Yu}$ VL, Weber R, Raoult D, Eds. Antimicrobial therapy and vaccines, $2^{\text {nd }}$ ed. New York: Apple Tree Productions, 2002; pp. 29-40.

[11] Markowitz SM, Williams DS. Effect of L-cysteine on the activity of penicillin antibiotics against Clostridium difficile. Antimicrob Agents Chemother 1985; 27: 419-21.
[12] Clarridge III JE, Zhang Q. Genotypic diversity of clinical Actinomyces species: phenotype, source, and disease correlation among genospecies. J Clin Microbiol 2002; 40: 3442-8.

[13] Pedersen BW, Petersen IR, Hansen BM. Genital actinomycosis diagnosis and treatment. Ugeskr Laeger 2003; 166: 472-5.

[14] Mabeza GF, Macfarlane J. Pulmonary actinomycosis. Eur Resp J $2003 ; 21: 545-51$.

Received: June 17, 2009

(C) Hansen et al.; Licensee Bentham Open.

This is an open access article licensed under the terms of the Creative Commons Attribution Non-Commercial License (http://creativecommons.org/licenses/by$\mathrm{nc} / 3.0 /$ ) which permits unrestricted, non-commercial use, distribution and reproduction in any medium, provided the work is properly cited. 